\title{
Leaping forward to 1997: Bankruptcy Law Reform in Hong Kong*
}

\author{
Charles D Booth ${ }^{* *}$
}

\section{Introduction}

As part of the effort to reform Hong Kong's laws in light of China's resumption of sovereignty on 1 July 1997, dramatic changes have recently been made to Hong Kong bankruptcy law. The Hong Kong Bankruptcy (Amendment) Ordinance $1996^{1}$ (the Bankruptcy (Amendment) Ordinance) was enacted in December 1996, less than seven months before Hong Kong became a Special Administrative Region of China. This Ordinance makes the first comprehensive changes to Hong Kong bankruptcy law in over a century and will affect the insolvency of both individual debtors and partnerships. ${ }^{2}$ The Ordinance amends or replaces much of the Hong Kong Bankruptcy Ordinance ${ }^{3}$ (the Bankruptcy Ordinance), which is based on English legislation dating back to the 1880s. The new Ordinance is expected to come into operation later in 1997 after the new Bankruptcy Rules are drafted.

The Bankruptcy (Amendment) Ordinance is the fruition of insolvency law reform that began in September 1990 when the Chief Justice and the AttorneyGeneral requested the Law Reform Commission of Hong Kong to conduct a review of both bankruptcy and liquidation law and practice in Hong Kong. The Law Reform Commission appointed the Sub-Committee on Insolvency,

* Copyright $(\mathcal{C} 1997$ by Charles D Booth. All rights reserved. This article is a revised version of a paper that I presented at the Academics Meeting at INSOL '97 in New Orleans, Louisiana on 23 March 1997. This article updates my earlier work, "Recent Developments in Hong Kong Bankruptcy Law Reform" [1993] 2 IIR 120.

** Associate Dean and Associate Professor, Faculty of Law, University of Hong Kong. BA, Yale University, 1981; JD, Harvard Law School, 1984.

1. Order No. 76 of 1996. As of 10 July 1997, the Ordinance had not yet come into operation.

2. In Hong Kong, the insolvency law of individuals is separate from that of companies. The former is called bankruptcy law and is contained in the Bankruptcy Ordinance (cap 6), Laws of Hong Kong (LHK) (1997), and the latter is called liquidation law and is contained in the Companies Ordinance (cap 32), LHK (1997). Hong Kong partnerships may be made bankrupt under the Bankruptcy Ordinance, but a Hong Kong partnership with eight or more partners may instead be wound up as an "unregistered company" under Part X of the Companies Ordinance.

3. Cap 6, LHK (1997). Although the Bankruptcy (Amendment) Ordinance has not yet come into operation, in this article its provisions are referred to as the "new law", and the provisions to be replaced as the "old law". 
under the Chairmanship of Professor ELG Tyler. The Sub-Committee commenced work on 12 November 1990, and issued its Consultative Document on Bankruptcy in August 1993. ${ }^{4}$ The Law Reform Commission circulated this consultative document for comment by interested professional bodies and others. After reviewing the submissions, the Law Reform Commission published its final recommendations for bankruptcy law reform in its Report on Bankruptcy in May 1995. The Commission's recommendations, with a few notable exceptions, ${ }^{6}$ adopted the proposals of the Sub-Committee on Insolvency. Most of the Commission's recommendations, in turn, were incorporated into the Bankruptcy (Amendment) Bill ${ }^{7}$ and then into the Bankruptcy (Amendment) Ordinance. Interestingly, both the Bankruptcy (Amendment) Bill and the enacted Bankruptcy (Amendment) Ordinance included some additional changes to the law that were not raised in either the Consultative Document on Bankruptcy or the Report on Bankruptcy. ${ }^{8}$

In conducting its review of Hong Kong bankruptcy law, the Sub-Committee on Insolvency considered the bankruptcy law and bankruptcy law reform efforts in many other jurisdictions, including England and Wales, Scotland, Singapore, New Zealand, and Australia. Both the Sub-Committee and the Law Reform Commission relied heavily on the recommendations of the Report of the Review Committee on Insolvency Law and Practice in England and Wales ${ }^{9}$ (the Cork Report), many of which were incorporated into the UK Insolvency Act 1986. They also benefited from the recommendations of the Law Reform Commission of Australia ${ }^{10}$ (the Harmer Report). Hong Kong often incorporates UK statutory provisions into Hong Kong law, and the Bankruptcy (Amendment) Ordinance, in great part, continues this practice. However, the new Ordinance also includes some provisions from other countries, as well as some new local provisions that cater to conditions in Hong Kong.

The problems with the old law have become more apparent given the increasing number of bankruptcies in Hong Kong. For example, from 1994/95 to $1995 / 96$, the number of bankruptcies jumped 53.5 per cent from 325 to 499. ${ }^{11}$ This increase was directly related to the weakness in Hong Kong's

4. The Law Reform Commission of Hong Kong SubCommittee on Insolvency, Consultative Document on Bankruptcy (August 1993) (Hong Kong: Hong Kong Government Printer, 1995).

5. The Law Reform Commission of Hong Kong, Report on Bankruptcy (May 1995) (Hong Kong Government Printer, 1993).

6. See, e.g. the Law Reform Commission's discussion of the jurisdictional criterion involving the presence of assets, ibid. at paras 2.12 2.36 , at $23-29$, and of the relation back doctrine, at paras 14.5-14.13 at 134-137.

7. Bankruptcy (Amendment) Bill 1996, Legal Supplement No.3 to the Hong Kong Government Gazette, I March 1996.
8. See e.g. the changes to the trustee's avoidance powers - Bankruptcy (Amendment) Ordinance, s. 36 (substituting new ss $49-51 \mathrm{~B}$ in the Bankruptcy Ordinance).

9. Insolvency Law and Practice; Report of the Revieze Committee (Cmnd 8558, 1982), under the Chairmanship of Sir Kenneth Cork, GBE.

10. The Law Reform Commission of Australia; General Insolvency Inquiry, Report No. 45 (1988), Mr RW Harmer, Commissioner-in-charge.

11. Hong Kong Official Receiver's Office Annual Departmental Report 1995-96 (1996) (Hong Kong Government Printer, 1996), Annex 6 (for the year 1 April 1995 to 31 March 1996). For the past 10 years the number of 
economy at that time and the relatively high unemployment. As reported by the Official Receiver, the leading causes of the 499 bankruptcies in 1995/96, in order of importance, were the following: liabilities incurred on personal guarantees; a drop in business; cash-flow problems - insufficient capital; excessive use of credit facilities; loss in investment; and lack of gainful employment. ${ }^{12}$ The leading factor involving personal guarantees probably follows from the financial difficulties experienced by Hong Kong companies. This is because management and ownership functions in Hong Kong are generally in the hands of the same individuals, and it is quite common for directors of Hong Kong companies to guarantee their companies' debts. Thus, when a Hong Kong company experiences financial problems, the bankruptcy of the company's directors often follows.

Although the Hong Kong real estate market and economy have recently improved, it is likely that the number of bankruptcies will remain high, at least for the new few years. It remains very expensive to operate a business in Hong Kong, and the price of real estate is again on an upward spiral. ${ }^{13}$ Weaker firms will be unlikely to survive in this environment. Earlier this year, both Hongkong Bank and Hang Seng Bank announced dramatic increases in their bad debt provisions - a 123 per cent increase at Hongkong Bank to HK $\$ 1.44$ billion and fivefold increase at Hang Seng Bank to HK\$715 million. ${ }^{14}$ Households are again spending dangerously high levels of their household income to service their mortgages ${ }^{15}$ and credit card interest rates are "excruciatingly high". ${ }^{16}$ Once the Bankruptcy (Amendment) Ordinance comes into operation, a growing number of individuals who are unable to cope with such financial pressures will probably file for bankruptcy to take advantage of the liberalised discharge provisions (discussed in Part XIV below).

This article presents an overview of the important changes to Hong Kong bankruptcy law made by the Bankruptcy (Amendment) Ordinance. It also discusses some of the trends and policy changes that emerged during the reform process and highlights the strengths and weaknesses of the new legislation.

bankruptcy cases has been as follows: 378 in $1986 / 87 ; 292$ in $1987 / 88 ; 194$ in $1988 / 89$; 178 in $1989 / 90 ; 226$ in $1990 / 91 ; 294$ in 1991/ $92 ; 313$ in $1992 / 93 ; 318$ in $1993 / 94 ; 325$ in $1994 / 95$; and 499 in $1995 / 96$. It should be noted, however, that even at these recent high levels of bankruptcy, the rate still remains lower than in other countries (para.1.2, at p. 1).

12. Ibid. Annex 13.

13. See "Local experts propose action on soaring property prices", BBC Summary of World Broadcasts, Part 3, Asia-Pacific (Xinhua news agency, 10 July 1997); Phillip Segal, "Asian Real Estate: No Firm Ground", International
Herald Tribune, 8 March 1997, p. 17

14. Deborah Orr, "HSBC reveals surprise provisions", South China Morning Post, 4 March 1997 , p. 1 .

15. Segal, op. cit., n 13.

16. See Jane Moir, "Credit card rates "excruciatingly high" ", South China Morning Post, 16 April 1996, p. 3 (citing consumer chiefs). For further discussion of factors likely to increase the number of insolvencies in Hong Kong, see Charles D Booth, "Living in Uncertain Times: The Need to Strengthen Hong Kong Transnational Insolvency Law" (1996) 34 Columbia Journal of Transnational Law 389, at 435-438. 


\section{Grounds for presenting a bankruptcy petition}

The changes to the grounds for presenting a bankruptcy petition incorporate one of the most far-reaching changes in the new law - the abolition of the concept of "acts of bankruptcy". This concept, which can be traced back to early English statutes enacted in the Middle Ages,${ }^{17}$ requires that a debtor must commit an "act of bankruptcy" before creditors are allowed to petition for the debtor's bankruptcy. Most of the "acts of bankruptcy" listed in old s. 3 of the Bankruptcy Ordinance set out various types of wrongful conduct by a debtor, e.g. making a fraudulent conveyance ${ }^{18}$ or removing one's property from Hong Kong with the intent to defeat or delay one's creditors. ${ }^{19}$ Many of the acts of bankruptcy, such as beginning "to keep house", are archaic and are rarely relied upon by creditors. In spite of the many possible acts of bankruptcy specified in the Bankruptcy Ordinance, probably 95 per cent of bankruptcy cases are commenced by creditors relying on a debtor's failure to comply with a bankruptcy notice under old s. $3(1)(\mathrm{g})$ of the Bankruptcy Ordinance. ${ }^{20}$

The aim of the Law Reform Commission was to enact new grounds for presenting a bankruptcy petition that would be better utilised by creditors in Hong Kong. The new grounds will be as follows: (i) a debtor's failure to comply within three weeks with a statutory demand for the repayment of $\mathrm{HK} \$ 10,000$ or more, ${ }^{21}$ (ii) a debtor's failure to satisfy an execution of a judgment debt for HK $\$ 10,000$ or more; ${ }^{22}$ (iii) the absconding of a debtor (or the intention to abscond by a debtor) from Hong Kong and the "debtor knows or ought reasonably to know that his departure would result in defeat or delay for his creditors"; ${ }^{23}$ and (iv) a debtor's default in connection with a voluntary arrangement. ${ }^{24}$ The first three grounds have their origins in the former acts of bankruptcy, and the fourth ground reflects changes to the law to facilitate "workouts" for debtors.

The enactment of these grounds and the abolition of all but one of the acts of bankruptcy that were premised on wrongful behaviour by the debtor demonstrate that bankruptcy will come to be based more on the poor financial state of a debtor rather than on a debtor's actions. This is an appropriate policy shift which acknowledges that bankruptcy is often caused by a debtor's financial incompetence or mistakes, rather than by morally blameworthy behaviour. Although society as a whole benefits from the growing availability of credit, individual debtors at times suffer - e.g. some debtors become overextended

17. See Act Against Such As Do Make Bankrupt, 34 and 35 Henry VIII, Chapter 4 (1542); 13 Eliz, Ghapter 7 (1571).

18. Bankruptcy Ordinance, old. s. $3(1)(\mathrm{b})$.

19. Ibid, s. 3(1) (d).

20. Consultative Document on Bankruptcy, op. cit., n. 4, para. 2.13, at p. 10.

21. Bankruptcy (Amendment) Ordinance, s. 4 (substituting new ss 6 and $6 \mathrm{~A}(1)(\mathrm{a}),(2)$ in the Bankruptcy Ordinance).
22. Bankruptcy (Amendment) Ordinance, s. 4 (substituting new ss 6 and $6 \mathrm{~A}(1)(\mathrm{b})$ in the Bankruptcy Ordinance).

23. Bankruptcy (Amendment) Ordinance, s. 4 (substituting new s. 6(4) in the Bankruptcy Ordinance).

24. Bankruptcy (Amendment) Ordinance, s. 4 (substituting new s. 3(1)(c) in the Bankruptcy Ordinance); and s. 13(substituting new s. 20L in the Bankruptcy Ordinance. 
and then default on their consumer debts, while others invest at the wrong time and get hurt by a stock market or real estate crash.

However, the Law Reform Commission has not based the new grounds solely on the financial difficulties of a debtor, because it has included a ground based on the absconding of a debtor or the intention of a debtor to abscond. The Sub-Committee on Insolvency was aware of reported instances of absconding debtors in the run-up to 1997 and was troubled by reports of debtors incurring substantial debts that they had no intention of repaying. ${ }^{25}$

The new grounds borrow much from UK law. In particular, grounds (i) and (ii) are adopted from ss 267 and 268 of the UK Insolvency Act 1986, and ground (iv) from ss 264 and 276. The new amendments also bring Hong Kong bankruptcy law into sync with the current practices in the Hong Kong Companies Ordinance ${ }^{26}$ (the Companies Ordinance) for use in compulsory liquidations. First, the period of statutory demand has been increased from one to three weeks. ${ }^{27}$ Secondly, a statutory demand will no longer have to be based on a judgment. ${ }^{28}$ (This change will save creditors unnecessary expense and time and enable them to commence bankruptcy earlier.) Thirdly, the language in new $\mathrm{s.6 \textrm {A }}(1)(\mathrm{b})$ of the Bankruptcy Ordinance regarding unsatisfied executions parallels the language in s. 178 (b) of the Companies Ordinance.

The abolition of the notion of "acts of bankruptcy" should be welcomed. However, as the Cork Report has noted:

" $[t]$ he elimination of the doctrine of the act of bankruptcy ... is not merely a question of modernising and simplifying the grounds upon which a creditor may initiate insolvency proceedings. It represents a fundamental change in the law of bankruptcy with far-reaching consequences." 29

These consequences may be seen in other amendments to the Bankruptcy Ordinance such as the abolition of the concept of "relation back" (discussed in Part XI below) and in the changes to the jurisdictional requirements.

\section{Jurisdiction of the court}

Certain jurisdictional criteria must be satisfied to ensure that a debtor has sufficient contacts and a geographical connection with Hong Kong to justify

25. Consultative Document on Bankruptcy, op. cit., n. 4 , para. 2.19, at p. 12.

26. Cap 32, LHK (1997).

27. Bankruptcy (Amendment) Ordinance, s. 4 (substituting new s.6A(1)(a) in the Bankruptcy Ordinance, which tracks the three-week period in s. 178 of the Companies Ordinance), However, new s.6C of the Bankruptcy Ordinance provides that a petition may be presented before the expiry of the three-week period "if there is a serious possibility that the debtor's property or the value of any of his property will be significantly diminished during that period and the petition contains a statement to that effect".

28. This follows from the deletion of the old s. $3(1)(\mathrm{g})$ of the Bankruptcy Ordinance by s. 4 of the Bankruptcy (Amendment) Ordinance.

29. Cork Report, op. cit., n. 9, para. 530, at p. 126. 
his bankruptcy in Hong Kong. Under the old scheme, which is based on the notion of acts of bankruptcy, jurisdictional criteria have to be satisfied at the time of the occurrence of an act of bankruptcy ${ }^{30}$ and in the case of a creditor's petition at the time that (or, for some of the factors, within one year before the date on which) the bankruptcy petition is filed. ${ }^{31}$ Section 4 of the Bankruptcy (Amendment) Ordinance repeals the twofold approach of the old regime and replaces it with a new s. 4, which is based on s. 265 of the UK Insolvency Act 1986:

"(1) A bankruptcy petition shall not be presented to the court ... unless the debtor -

(a) is domiciled in Hong Kong;

(b) is personally present in Hong Kong on the day on which the petition is presented; or

(c) at any time in the period of 3 years ending with that day-

(i) has been ordinarily resident, or has had a place of residence, in Hong Kong; or

(ii) has carried on business in Hong Kong.

(2) The reference in sub-section (1)(c) to a debtor carrying on business includes -

(a) the carrying on of business by a firm or partnership of which the debtor is a member; and

(b) the carrying on of business by an agent or manager for the debtor or for such a firm or partnership."

These new jurisdictional criteria increase the relevant period of residency and carrying on of business from one to three years. Domicile, residence or the carrying on of business in Hong Kong on the date of the bankruptcy filing, provides a clear jurisdictional connection between a debtor and Hong Kong. Although residence or the carrying on of business within the prior three-year period does not demonstrate as clear a connection, the inclusion of these criteria is justified by the need to gain jurisdiction over absconding debtors who run up debts in Hong Kong, but then flee from Hong Kong with their assets. ${ }^{32}$ By giving the courts bankruptcy jurisdiction over such individuals, these criteria enable a bankruptcy trustee to begin a search for assets and to seek recognition abroad for the Hong Kong bankruptcy. Bankruptcy orders issued in cases involving absconding debtors who have emigrated and no longer reside or carry on business in Hong Kong would be enforceable in the United Kingdom under s. 426 of the UK Insolvency Act 1986. However, in other jurisdictions, it is arguable that enforcement would not be given as the bankruptcy proceedings in Hong Kong would not be the primary bankruptcy proceeding. The

30. Bankruptcy Ordinance, old s. 3(2).

31. Ibid, old s. 6(1)(d).
32. See Fletcher and Crabb, Insolvency Act 1986 (Current Law Statutes Annotated, 1986), 45/ 265 at pp. 45-216. 
primary proceeding would more likely be in the jurisdiction in which the debtor was domiciled or, perhaps, had his primary residence. ${ }^{33}$

The jurisdictional factor based on personal presence is the weakest criterion because it enables the court to enter a bankruptcy order against a person who might have only a tenuous connection with Hong Kong, such as a short-term tourist or an in-transit passenger. However, pursuant to new s. 5(3) of the Bankruptcy Ordinance (which is modelled on s. 266(3) of the UK Insolvency Act 1986), the court has the discretion to dismiss a bankruptcy petition or to stay proceedings on such terms and conditions as it thinks fit. It must also be kept in mind that the inclusion of the personal presence criterion will "catch" persons who do not satisfy the definition of residency, but who have nevertheless run up unpaid debts in Hong Kong.

Unfortunately, the Law Reform Commission rejected the recommendation of the Sub-Committee on Insolvency that the presence of assets should also be a jurisdictional criterion. ${ }^{34}$ This omission leaves a gap in the law that is of importance in cross-border insolvencies - assuming that none of the other jurisdictional criteria are satisfied, a foreign debtor might have assets in Hong Kong that are beyond the reach of a foreign trustee, yet also outside the scope of Hong Kong bankruptcy law - which will work to the advantage of fastmoving creditors and to the disadvantage of unsecured creditors generally. ${ }^{35}$

\section{Minimum debt and statutory deposit}

The minimum debt upon which a creditor may petition for a debtor's bankruptcy has been raised from $\mathrm{HK} \$ 5,000$ to $\mathrm{HK} \$ 10,000 .^{36}$ The $\mathrm{HK} \$ 5,000$ level was introduced into legislation in 1976. Given the high inflation rate in Hong Kong, HK $\$ 5,000$ in 1976 would be equivalent to more than three times that amount today. Thus, the increase to $\mathrm{HK} \$ 10,000$ seems reasonable. ${ }^{37}$ In addition, the Law Reform Commission found that the higher amount was more in line with the minimum debt level in England and Wales and Australia. ${ }^{38}$

Raising the minimum debt to $\mathrm{HK} \$ 10,000$ will have little effect on the ability of most creditors to petition, given that creditors rarely petition for less than that amount anyway ${ }^{39}$ (at least in part because of the statutory deposit requirement, which is discussed below). Although the increased minimum debt might hinder the ability of employees to petition for the bankruptcy of their employers,

33. For further discussion of these cross-border insolvency issues, see Charles D Booth, "The Transnational Aspects of Hong Kong Insolvency Law" (1995) 2 Southwestern Journal of Law and Trade in the Americas 1 at 78-79.

34. Report on Bankruptcy, op. cit., n.5, paras $2.12-.36$, at pp. $23-29$.

35. For further discussion of this issue and for a more complete critique of the Law Reform Commission's position, see Booth, op. cit., n. 16 , at pp. $426-429$.

36. See Bankruptcy (Amendment) Ordinance, s. 4 (substituting new s.6(2)(a) in the Bankruptcy Ordinance).

37. New s. 6(5) of the Bankruptcy Ordinance will enable the Financial Secretary to increase the amount to keep pace with inflation.

38. Report on Bankruptcy, op. cit., n. 5, paras $3.5-.6$, at p. 33 .

39. Ibid., para. 3.9 at p. 34 . 
such employees will remain protected by s. 16(1)(a) of the Protection of Wages on Insolvency Ordinance, ${ }^{40}$ which enables the Commissioner for Labour to make ex gratia payments from the Protection of Wages on Insolvency Fund to employees in cases in which a bankruptcy petition may not be filed against their insolvent employers solely because the minimum debt cannot be met.

Raising the minimum debt level is in keeping with the rationale that bankruptcy law should generally be dependent on a debtor's inability to pay, as it protects the debtor against petitions based on smaller claims that the debtor might well be able to pay back over time. If a debtor believed that he could not repay debts that amounted to less than $\mathrm{HK} \$ 10,000$, he could always file a voluntary petition for which there is no minimum amount. ${ }^{41}$

One reason why raising the minimum debt level by $\operatorname{HK} \$ 5,000$ will have little effect on the number of bankruptcy cases is that the petitioner must make a statutory deposit with the Official Receiver to cover the preliminary expenses of the case. Under Bankruptcy Rule 52(1) ${ }^{42}$ upon the presentation of a bankruptcy petition the petitioner must deposit $H K \$ 11,250$ with the Official Receiver. Further, under Bankruptcy Rule 52(1), the court may direct the petitioner to deposit additional sums to cover the fees and expenses to be incurred by the Official Receiver.

The Law Reform Commission has recommended that the statutory deposit be reduced to $\operatorname{HK} \$ 5,000$ for both creditors and debtors. ${ }^{43}$ This change will probably be reflected in the new Bankruptcy Rules. The current level came into effect in 1996, replacing the level set in 1985 when the deposit was raised by 1,000 per cent from $\mathrm{HK} \$ 1,000$ to $\mathrm{HK} \$ 10,000$. The 1985 increase was part of a deliberate policy to restrict the number of bankruptcy petitions, which proved at least partly successful. ${ }^{44}$ By now lowering the statutory deposit, the Bankruptcy (Amendment) Ordinance will undo the effect of this earlier change. As the Law Reform Commission has noted, "Recourse to bankruptcy proceedings should be within the financial reach of as many people as possible ...". ${ }^{45}$

The recommendation of the Law Reform Commission to set the statutory deposit at $\operatorname{HK} \$ 5,000$ strikes a reasonable compromise - it will make petitioning for bankruptcy more affordable for creditors, yet still enable the Official Receiver (who usually serves as the trustee) to cover the initial expenses and costs. In cases in which further deposits are necessary to cover the additional administration expenses and costs of the Official Receiver (such as the cost of legal proceedings or investigations), the Law Reform Commission has recommended that the Official Receiver contact creditors earlier than he has been doing. ${ }^{46}$

40. Cap 380, LHK (1997).

41. See Bankruptcy (Amendment) Ordinance, s. 7 (substituting new s. $10(3)$ in the Bankruptcy Ordinance), which continues the prior policy.

42. Cap 6, sub leg A, LHK (1997).
43. Report on Bankruptcy, op. cit., n.5, para. 4.13 , at p. 39.

44. Ibid., para. 4.8 , at p. 38 .

45. Ibid., para. 4.10 , at p. 38 .

46. Ibid., para. 4.14 , at p. 39. 


\section{Bankruptcy orders}

Another major change to existing law is the replacement of a two-step procedure - involving the entering of a receiving order and then the making of an adjudication order - with a one-step procedure involving the making of a single bankruptcy order. The theory behind the two-step procedure was that it provided the debtor with a period in which he could either pay his creditors in full or enter into a scheme of arrangement or composition with them. ${ }^{47}$ In practice, however, such settlements have been rare, and the entering of a receiving order is usually followed by the making of an adjudication order. ${ }^{48}$

Debtors and creditors should both benefit from the one-step procedure and its related changes. Because the scheme of arrangement/composition provisions have been replaced with a voluntary arrangement scheme (discussed in Part VI below), debtors will have better prospects for repaying their debts out of bankruptcy, ${ }^{49}$ and creditors will probably receive higher recoveries. ${ }^{50}$ If bankruptcy does result, creditors will also benefit from the lower costs and from the earlier appointment of a trustee.

A one-step bankruptcy procedure will also track the existing one-step procedure for company liquidations. The enactment of this one-step procedure has led to an amendment regarding the stay of actions and proceedings, which will also track the company law provision. Old s. 12(1) of the Bankruptcy Ordinance provides that upon the making of a receiving order, no creditor with a provable debt may commence any action or other legal proceedings against the debtor, except with the leave of the court. Section 8 of the Bankruptcy (Amendment) Ordinance amends s. 12(1) so that it corresponds to s. 186 of the Companies Ordinance and explicitly stays the commencement of both new and existing actions and proceedings upon the making of the bankruptcy order.

A continued weakness in the provisions regarding stays is the retention of the policy of generally not affecting the rights of secured creditors. The Law Reform Commission was of the view that the rights of secured creditors should not be affected by the making of a bankruptcy order, except in regard to rights to the debtor's family home (discussed in Part X below). ${ }^{51}$ Although this restriction should be welcomed, it is unfortunate that the Commission failed to recommend that the rights of secured creditors should be stayed generally. Such a reform would have been to the benefit of both debtors and unsecured creditors, because it would have led to more post-petition voluntary arrangements.

New s. 33 of the Bankruptcy Ordinance (which is set forth in s. 24 of the Bankruptcy (Amendment) Ordinance) also applies to bankruptcy orders. This provision, which is based in great part on s. 282 of the UK Insolvency Act

47. Ibid., para. 5.7 , at p. 42 .

48. See ibid., paras 5.7-5.8, at p. 42 .

49. See ibid., para. 5.10 , at p. 39 .
50. See n. 56 below and accompanying text.

51. Report on Bankruptcy, op. cit., n. 5, para. 5.12, at p. 43. 
1986, gives the court the power to annul the bankruptcy order under certain conditions and ameliorates some of the harsher aspects for debtors that are contained in old s. 33 of the Bankruptcy Ordinance.

\section{Individual voluntary arrangements}

As noted above, the practice in Hong Kong has been that an adjudication order generally follows the making of a receiving order, since by the time the bankruptcy petition has been filed it is too late for a debtor to negotiate a settlement with his creditors. One of the most important aspects of the new bankruptcy law is the adoption of an individual voluntary arrangement procedure that is based on Part VIII of the UK Insolvency Act 1986. This procedure enables a debtor to seek relief at an earlier stage of his financial difficulties and thereby avoid the commencement of a bankruptcy case.

Section 13 of the bankruptcy (Amendment) Ordinance includes new s. 20(2) of the Bankruptcy Ordinance, which will enable debtors to seek the entering of an interim order that will provide the debtor with a moratorium during the period in which the order is in effect, no bankruptcy petition may be presented or proceeded with against the debtor and no other proceedings, execution, legal process, or distress ${ }^{52}$ may be commenced or continued against the debtor except with the leave of the court. As in bankruptcy, however, the moratorium will not affect the rights of secured creditors to realise their security. In addition, pursuant to new s. 20F (3) of the Bankruptcy Ordinance, secured creditors are required to consent to any proposed voluntary arrangement that affects their rights. Thus, secured creditors, in effect, have veto power over any proposed voluntary arrangement. This protection for secured creditors seems unnecessary, indeed undesirable, in those cases in which it can be proved that the interests of secured creditors are protected by the proposed voluntary arrangement. ${ }^{53}$

Although the voluntary arrangement procedure will be most useful to debtors who wish to avoid bankruptcy, it will also be available to undischarged bankrupts. ${ }^{54}$ In such cases, the court will have the discretion to annul the bankruptcy order.

A complete analysis of the voluntary arrangement procedure is outside the scope of this article, but it is important to note that the availability of the voluntary arrangement procedure offers debtors a realistic opportunity to avoid the harsh consequences of bankruptcy and of the related disqualifications

52. Bankruptcy Ordinance, new s. 20(2). Compare UK Insolvency Act 1986, s. 252(2) (not including a prohibition against distress).

53. For example, see ss $1129($ b) (l), (b)(2)(A) and $1325(a)(5)$ of the US Bankruptcy Code (United States Bankruptcy Reform
Act of 1978, Pub L No.95-598, 92 Stat 2549 (codified as amended in 11 USC (1997), in scattered sections of 28 USC (1997), and in scattered sections of other titles).

54. Bankruptcy Ordinance, new s. 20I. 
that follow, such as the restriction against serving as a company director without the leave of the court. ${ }^{55}$ Unsecured creditors are also likely to recover more in voluntary arrangements than they would in bankruptcy, as has been the experience in the United Kingdom. ${ }^{56}$

\section{The role of creditors and the trustee}

The new amendments make many changes to the law regarding the balance of responsibilities between the trustee and the creditors. The Official Receiver serves as the trustee in almost all bankruptcy cases in Hong Kong. ${ }^{57}$ Historically, creditors in Hong Kong have been reluctant to play a major role in bankruptcies and, in many cases, the creditors' lack of interest has made it difficult for the quorum requirements for creditors' meetings to be satisfied. In such cases, the Official Receiver has been forced to take extra time and effort to comply with the bankruptcy procedures. To address these problems, the Official Receiver proposed that the bankruptcy procedures should be streamlined and that he should be given the discretion to dispense with various meetings and requirements. Both the Sub-Committee on Insolvency and the Law Reform Commission supported these recommendations. ${ }^{58}$ The result has been the enactment of a variety of provisions and proposed bankruptcy rules along the lines of the provisions in the UK Insolvency Act 1986 and the related UK Insolvency Rules 1986. ${ }^{59}$

One of the primary changes made by the Bankruptcy (Amendment) Ordinance, based on ss 293 and 294 of the UK Insolvency Act 1986, is that the Official Receiver has been given the discretion to cancel unnecessary meetings and to decide whether to serve as the bankruptcy trustee. Until the enactment of the recent bankruptcy reforms, the primary issue to be resolved at the first meeting of creditors was whether the debtor should be adjudicated bankrupt or whether a composition or scheme of arrangement should be accepted by the creditors. ${ }^{60}$ Now that the receiving order and the adjudication order have been consolidated into a single bankruptcy order, the primary reason to hold the first meeting of creditors has been removed. Thus, new s. 17A(1) requires the Official Receiver to decide (in cases not involving a summary administration of the bankrupt's assets under s. 112A of the Bankruptcy Ordinance) as soon as practicable within 12 weeks from the date of the bankruptcy order, whether or not to call a first meeting of creditors for the purpose of appointing a trustee of

55. See Companies Ordinance, s. 156.

56. See Sealy and Milman, Annotated Guide to the Insolvency Legislation (4th edn, 1994), p. 313: general comment on Part VIII of the UK Insolvency Act 1986.

57. For example, between 1959 and 1992, the Official Receiver served as trustee in all but four cases (Annual Departmental Report of the Hong
Kong Registrar General (1991-1992) (Hong Kong Government Printer, 1992), para. 108, at p. 40.

58. See, e.g. Consultative Document on Bankruptcy, op. cit., n. 4, Chapter 9, at pp. 60-65; Report on Bankruptcy, op. cit., n. 5, Chapter 8, at pp. 67-72.

59. (SI 1986/1925).

60. See Bankruptcy Ordinance, old s. 17(1). 
the bankrupt's estate. If the Official Receiver does not call such a meeting, he becomes the trustee of the debtor's estate, and must give notice to all creditors of his decision. ${ }^{61}$ New s. 17B, in turn, allows creditors to request the Official Receiver to hold a meeting for the purpose of selecting a trustee, and the Official Receiver must summon such a meeting if the request appears to be made with the concurrence of not less than one-quarter, in value, of the bankrupt's creditors.

The Law Reform Commission recommended other changes to streamline the meetings' procedures. For example, the Commission found it wasteful to continue requiring the "creditors' committee" (the new name for the "committee of inspection") ${ }^{62}$ to meet on a monthly basis, as is the policy pursuant to old s.24(3) of the Bankruptcy Ordinance. The Commission therefore recommended that the first meeting of the committee be held within three months of the trustee's appointment, or of the establishment of the committee, whichever is later ${ }^{63}$ In addition, the Commission proposed that subsequent meetings be held when determined by the trustee or, if so requested, by a member of the committee or as specified by the creditors' committee. ${ }^{64}$ The Commission also recommended that the quorum for meetings of creditors be reduced to one creditor present or represented at a meeting. ${ }^{65}$ These changes will probably be reflected in the new Bankruptcy Rules.

Although recommending many changes to streamline the practices regarding the creditors' committees and creditors' meetings, the Law Reform Commission was cognisant of the need to enable creditors to participate in the bankruptcy process. For example, the Commission refused to recommend the adoption of the UK practice of not appointing a creditors' committee where the Official Receiver serves as the trustee. It noted that since the Official Receiver serves as the trustee in most bankruptcies, adoption of this provision "would effectively mean that creditors' committees would cease to exist". ${ }^{66}$ Moreover, several of the amendments to the Bankruptcy Ordinance increase the control of both the court and unsecured creditors over the trustee. For example, new s. 61 of the Bankruptcy Ordinance includes three additional powers for which the trustee must seek the permission of the creditors' committee before taking action. ${ }^{67}$ New s. $61 \mathrm{~A}$, in turn, provides that " $[\mathrm{t}] \mathrm{he}$ exercise by the trustee of the powers conferred by sections 60 and 61 [of the Bankruptcy Ordinance] shall be subject to the control of the court, and any creditor may apply to the court with

61. Bankruptcy (Amendment) Ordinance, s. 11 (substituting new s.17A(3), (4) in the Bankruptcy Ordinance).

62. See Bankruptcy (Amendment) Ordinance (amending Bankruptcy Ordinance, s. 24).

63. Report on Bankruptcy, op. cit., n.5, para.9.10, at p. 78 (basing this recommendation on r. 6.153 of the UK Insolvency Rules 1986).
64. Report on Bankruptcy, op. cit., n. 5, para.9.10, at p. 78 .

65. Ibid., para.8.14, at pp. 70-71 (basing this recommendation on r. 12.4A of the UK Insolvency Rules 1986).

66. Report on Bankruptcy, op. cit., n. 5, para. 9.15, at p. 79.

67. See Bankruptcy (Amendment) Ordinance, s. 41 . 
respect to any exercise or proposed exercise of any of those powers" ${ }^{68}$ Finally, amendments based on s. 304(1) of the UK Insolvency Act 1986 were made to s. 84 of the Bankruptcy Ordinance which, as noted by the Law Reform Commission, go "some way towards imposing a statutory duty on trustees in providing that a trustee may be liable for his actions in the event that he behaves improperly" in several defined circumstances. ${ }^{69}$

The Law Reform Commission also made several recommendations that liberalise the treatment of creditors. For example, the Commission recommended that agreement of members of the creditors' committee to a resolution may be obtained by post, which will avoid the necessity of calling a meeting. ${ }^{70}$ Similarly, the Commission recommended that members of the creditors' committee should be capable of being represented by any person in possession of a letter of authority, rather than requiring that that person hold a general proxy or power of attorney, as is the practice under old s. 24(2) of the Bankruptcy Ordinance. ${ }^{71}$ This practice has been repealed by $\mathrm{s.} 15$ of the Bankruptcy (Amendment) Ordinance.

Many of these amendments and recommendations strike a reasonable balance between streamlining the bankruptcy process and increasing the discretion of the Official Receiver (or trustee) on the one hand, and facilitating the involvement of unsecured creditors on the other. However, there are a few exceptions, such as cancelling the first meeting of creditors, which unfortunately demonstrate that improving efficiency was ultimately a more important goal than increasing creditor participation.

The onus will now be on the creditors to contact each other and to seek support if they wish to request the Official Receiver to hold the first meeting, and it is possible that the views of minority creditors who cannot meet the onequarter in value requirement will be ignored. ${ }^{72} \mathrm{~A}$ further consequence of this change is that it might become more difficult to gain foreign recognition and enforcement in cases in which, over the objection of minority creditors, the Official Receiver does not hold a first meeting of creditors. ${ }^{73}$

In addition, some of the new time periods are too generous to the Official Receiver or trustee. The Official Receiver should only be given four rather than 12 weeks from the date of the bankruptcy order to decide whether or not to hold the first meeting of creditors. Similarly, it would seem appropriate that the first meeting of the creditors' committee should be held within two months of the trustee's appointment, or of the establishment of the committee,

68. Ibid., s. 42.

69. Report on Bankruptcy, op. cit., n. 5, para.9.33, at pp.84-85. See Bankruptcy (Amendment) Ordinance, s. 46.

70. Report on Bankruptcy, op. cit., n.5., para. 9.13, at p. 79 .

71. Ibid., para.9.11, at p. 78. This change will probably appear in the new Bankruptcy Rules.
72. This concern, in fact, was raised by a minority in the Sub-Committee on Insolvency. See Consultative Document on Bankruptcy, op. cit., n. 4, para. 9.13, at pp. 63-64.

73. For further discussion of this issue, see Booth, "Recent Developments in Hong Kong Bankruptcy Law Reform" [1993] 2 IIR 120 at $138-139$. 
whichever is later, rather than within three months as has been proposed by the Law Reform Commission.

Given the uncertainties surrounding the future independence of the civil service in post-handover Hong Kong, a more fundamental objection can be made against increasing the discretion of the Official Receiver as to whether to serve as the trustee, as well as against decreasing the quorum for creditors' meetings. In short, during this period of transition the Official Receiver's role in bankruptcies should be decreased. To achieve this goal it would be best to decentralise the insolvency process - for example by appointing more private trustees and allowing unsecured creditors to play a greater role in their selection - and to ensure generally that unsecured creditors are more actively involved in the bankruptcy process. Thus, creditor meetings should be required to involve more than one creditor.

Unsecured creditors would be more likely to participate in bankruptcies if there were strong incentives to increase their participation, such as an improved likelihood of receiving greater dividends. In fact, s. 36 of the Bankruptcy (Amendment) Ordinance does just this by providing a trustee with improved and more powerful avoidance powers (discussed in Part XVII below) that are modelled on ss 339 to 342 of the UK Insolvency Act 1986. With these improved weapons in his arsenal, a trustee will be more likely to undo prior transactions entered into by the debtor, and thereby increase the size of the estate available for distribution. It is likely that creditors will take greater interest in those cases in which trustees exercise these new powers. Thus, it might well turn out that it was unnecessary to enact some of the changes that are premised on poor creditor participation.

\section{Statement of affairs}

The Bankruptcy (Amendment) Ordinance makes several changes to the law regarding the statement of affairs that will abolish the inefficient procedures that the Official Receiver must follow at present. The old law requires the debtor to file the statement of affairs within seven days of the receiving order in cases commenced by a creditor, ${ }^{74}$ and within three days in cases commenced by the debtor himself. ${ }^{75}$ New s. 18(1) of the Bankruptcy Ordinance sets a more realistic time-limit of 21 days of the bankruptcy order in cases commenced by a creditor, and new s. 10(2) requires the debtor to file the statement of affairs with the petition when petitioning for his own bankruptcy. ${ }^{76}$ Given that the debtor is aware of his financial position at the time he files the petition, it seems

74. Bankruptcy Ordinance, old s. 18(2)(b).

75. Ibid., old s. 18(2)(a).

76. See Bankruptcy (Amendment) Ordinance, ss 12 and 7 , respectively. These enactments track the requirements in $\mathrm{s} .288(1)$ (regarding creditors' petitions) and s. 272(2) (regarding debtors' petitions) of the UK Insolvency Act 1986. 
reasonable that he should share this information with the Official Receiver at that time.

The Law Reform Commission recommended two other changes to streamline the procedures regarding statements of affairs. The first was to give the Official Receiver the discretion to dispense with the statement of affairs in cases where he considers it unnecessary, without having to apply for an order of the court as is presently required under Bankruptcy Rule $81 \mathrm{~A} .{ }^{77}$ The second was to give the Official Receiver the power to extend the time for submission of the statement of affairs without having to file a certificate in court, as is currently required under Bankruptcy Rule 82. ${ }^{78}$ These changes should soon appear in the amended Bankruptcy Rules.

In addition, new s. 18(4) of the Bankruptcy Ordinance has been enacted to clarify the guidelines regarding a bankrupt who commits contempt of court. ${ }^{79}$ The new wording explicitly requires the bankrupt to submit a proper statement of affairs. Section 18(4) tracks the language of s. 288(4) of the UK Insolvency Act 1986.

\section{Public and private examination}

Examinations are an important means for the trustee and the creditors to gather information about the debtor's financial situation and to discover the whereabouts of his assets. Public examinations involve examinations of the debtor; private examinations usually involve examinations of third parties, but may also involve examinations of the debtor.

The presumption under old s. 19 of the Bankruptcy Ordinance is that the public examination should be held, although old s. 19A enables the Official Receiver to make an application to dispense with the examination. In practice, however, holding a public examination is the exception rather than the rule; of the more than 2,600 cases in which a receiving order was made between April 1983 and March 1994, a public examination was held in only 53 cases ${ }^{80}$ New s. 19(1) reflects this reality and changes the presumption - the public examination will only be held pursuant to an application by the Official Receiver. ${ }^{81}$ New s. 19(2) and (3), in turn, requires the Official Receiver to apply for an examination pursuant to a request from a creditor with or without the concurrence of not less than one-quarter in value of such creditors. However, where less than one-quarter in value of the creditors concurs, the court has the discretion to decline to direct that a public examination be held.

\footnotetext{
77. Report on Bankruptcy, op. cit., n.5, paras 10.13-10.15, at pp. 90-91.

78. Ibid., paras 10.16-10.17, at p. 91. This change would track the requirements in s. 190(3) of the Companies Ordinance.

79. See Bankruptcy (Amendment) Ordinance,
}

s. 12.

80. Report on Bankruptcy, op. cit., n.5, para. 11.2 , at p. 94 .

81. See Bankruptcy (Amendment) Ordinance, s. 13 (substituting new s.19 in the Bankruptcy Ordinance). 
In its report, the Law Reform Commission discussed in some length the issue of a debtor's self-incrimination at a public examination and noted that the application of the Hong Kong Bill of Rights ${ }^{82}$ and of recent Hong Kong caselaw now prohibits a bankrupt's answers to questions at his public examination from being used against him if he has already been charged with or convicted of a criminal offence. ${ }^{83}$ The Commission also noted that allowing bankrupts to decline answering questions at public examinations would enable bankrupts to conceal their assets. ${ }^{84}$ Thus, new s. 19(9) and (10) requires a bankrupt to answer all questions put to him, but his answers may not be used as evidence against him in criminal proceedings other than for perjury.

New s. 19(5) provides that the Official Receiver, the Official Petitioner (where a criminal bankruptcy order has been made against the debtor), the trustee, a special manager, or any creditor who has submitted a proof may take part in the public examination. New s. 19(6), in turn, will enable a bankrupt at his own expense to employ legal representation at the public examination. New s. 19(7) provides that the bankrupt will have the right either to be read or to read the record of the examination, and s. 19(8) provides the court with the discretion to order that the costs of an examination be borne by creditors who required a public examination in those cases where the court finds that the examination was "frivolous or vexatious". This standard is an improvement over the lower standard recommended by the Sub-Committee on Insolvency. ${ }^{85}$

Private examinations are a powerful investigatory tool because they enable the trustee to question third parties about the bankrupt, his dealings or property, and, as recently provided for in amended s.29(3), on "any other matter the court considers relevant". ${ }^{86}$ The ability of a trustee or the Official Receiver to hold a private examination of a third party might well lead a bankrupt to volunteer information that such other individuals would be forced to provide. New s. $29(1 \mathrm{~A})$ provides that a third party respondent may be required to submit an affidavit "containing an account of his dealings with the bankrupt or to produce any documents in his possession or under his control relating to the bankrupt or the bankrupt's dealings, affairs or property". These changes are based on s. 366(1) of the UK Insolvency Act 1986.

New s. 29(3A) and (3B) provides that every person examined under s. 29 must answer all questions put to him, but that evidence obtained in the examination may not be used against him in criminal proceedings except for purposes of perjury. Finally, amended s. 29(4) and (5) provides that "[i]f on the examination of any person it appears to the court" that he is indebted to the bankrupt or has in his possession any property of the bankrupt, the court

82. Hong Kong Bill of Rights Ordinance (cap 383), LHK 1997.

83. Report on Bankruptcy, op. cit., n.5, paras $11.5-11.7$ at pp. $96-97$.

84. See ibid., paras 11.13-11.17, at p. 98 .

85. See the Consultative Document on Bankruptcy, op. cit., n. 4, para. 12.33, at p. 96 (proposing a standard of whether the court considered it "unnecessary, on the evidence of the questions asked, to have held the examination").

86. See Bankruptcy (Amendment) Ordinance, s. 19 (amending s. 29 of the Bankruptcy Ordinance). 
may order the individual to pay the debt in full or in part, or to deliver the property or any part thereof to the Official Receiver or the trustee. This changes the practice in old s. 29(4) and (5), which requires that for the court to make such an order the individual must first admit that he is indebted to the debtor or that he has in his possession property. The precedent for amended s. 29(4) and (5) is s. 31(4) and (5) of the Singapore Bankruptcy Act 1888. ${ }^{87}$ The Law Reform Commission recommended the adoption of this provision rather than the related provision in s. 367(1) and (2) of the UK Insolvency Act 1986, because the UK provision appears to enable a court to order any person to pay a debt or deliver property to the official receiver as a result of information obtained in the examination of another party. ${ }^{88}$

A further amendment related to the private examination is new s.30D, which enables the court to order the Commissioner of Inland Revenue to produce various tax documents of the bankrupt. ${ }^{89}$ Section 30D is based on s. 369 of the UK Insolvency Act 1986. Curiously, unlike its UK counterpart, s. $30 \mathrm{D}$ is not applicable to a public examination of a bankrupt.

\section{$\mathrm{X}$. The bankrupt's property divisible among creditors}

The old provisions regarding the bankrupt's property divisible among creditors are among the most outdated provisions in the Bankruptcy Ordinance. Old s. 43 provides that the bankrupt is entitled to retain goods of a value of HK $\$ 3,000$, inclusive of his tools of trade and necessary wearing apparel and bedding of himself and his dependants. In practice, the trustee usually ignores the limitation. ${ }^{90}$ New s. $43^{91}$ is based on s. 283 of the UK Insolvency Act 1986. Under new s. 43(2), the HK $\$ 3,000$ limitation has been removed and a bankrupt will be entitled to retain:

"(i) such tools, books, vehicles, and other items of equipment as are necessary to the bankrupt for use personally by him in his employment, business, or vocation; (ii) such clothing, bedding, furniture, household equipment and provisions as are necessary for satisfying the basic domestic needs of the bankrupt and his family." 92

Another important aspect of new s. 43 is the abolition of the outdated doctrine of "reputed ownership". This doctrine held that "if the debtor appeared to be in possession of property which secretly belonged to another,

\footnotetext{
87. See Report on Bankruptcy, op. cit., n.5, para. 12.16 , at p. 111 .

88. Ibid., paras 12.17-12.18, at p. 111 .

89. See Bankruptcy (Amendment) Ordinance, s. 21

90. Report on Bankruptcy, op. cit., n. 5,
}

para. 13.5, at p. 121.

91. See Bankruptcy (Amendment) Ordinance, s. 31 (substituting new ss $43-43 \mathrm{~F}$ ).

92. This provision tracks the language of s. 283(2) of the UK Insolvency Act 1986. 
that would boost his creditworthiness, and therefore his creditors should be entitled to treat that property as part of the bankrupt's estate". ${ }^{93}$

Given that the new exemptions of property are much broader than in old s. 43, s. $43 \mathrm{~B}$ sets forth the procedure to enable the trustee to recover certain items of excess value. Another change to the law is in s. 43A, which provides that property which the bankrupt acquires post-petition does not vest in the trustee unless the trustee serves a notice in writing so to claim the property. (Previously, all post-petition property vested in the trustee, which proved administratively cumbersome. ${ }^{94}$ ) New s. $43 \mathrm{C}$ prescribes the time-limits on the trustee for recovering property under new s. $43 \mathrm{~A}$ and B. New s. 43D, in turn, provides that, notwithstanding s. 43 to $43 \mathrm{~B}$, the bankrupt or any creditor may apply to the court to include or exclude any particular item from the estate.

Other notable changes to the law include the enactment of new s. 43E, which authorises the court, on the application of the trustee, to make "an income payments order" pursuant to which the bankrupt must pay to his estate a portion of his income for the period in which the order is in effect. In addition, s. $43 \mathrm{~F}$ entitles the bankrupt to continue his occupation of the family home for a period of six months from the time of the making of the bankruptcy order, and in exceptional circumstances for a further period of six months. Finally, amended s.61(a) ${ }^{95}$ provides that a trustee (with permission of the creditors' committee) may allow a bankrupt to restructure his business where such restructuring is in the interests of the creditors. In so doing, amended s. 61 further provides that the trustee "may permit the debtor to retain any leasehold interest in property in which his business is situated".

These amendments greatly improve the law and strike a better balance between the interests of a bankrupt and his creditors. Under the new provisions, a bankrupt will be better able to provide for the basic domestic needs of himself and his family, but trustees and creditors will be able to ensure that the bankrupt does not benefit unjustly from the post-petition acquisition of property and earnings. In addition, allowing a bankrupt to retain his tools of trade etc., as well as to restructure his business, might well enable him to repay a higher percentage of his debts. Finally, the provision entitling the bankrupt to remain in his family home is one of the few areas in bankruptcy law in which the legislation allows the interests of the bankrupt to take precedence over the rights of secured creditors.

One potential weakness, however, in the new provisions is the greater amount of discretion given to the trustee. It would have been helpful if the recent amendments had included some monetary limits. In addition, it would have been beneficial if the amendments had explicitly addressed whether a bankrupt should be permitted to exempt various types of property, such as

93. Sealy and Milman, op. cit., n. 56 , p. 346 : general note to s. 283 of the UK Insolvency Act 1986.
94. See Report on Bankruptcy, op. cit., n.5, para. 13.51 at p. 130 .

95. See Bankruptcy (Amendment) Ordinance, s. 41.

Int. Insolv. Rev., Vol. 6: 183-209 (1997)

(C) 1997 John Wiley \& Sons, Ltd. 
unmatured life insurance contracts or the right to receive unemployment benefits, alimony, or pension benefits. ${ }^{96}$

\section{Relation back of the trustee's title}

Related to the concept of acts of bankruptcy is the notion that the commencement of a debtor's bankruptcy has relation back to the occurrence of the act of bankruptcy upon which a receiving order is made (or, where the debtor has committed more than one act, to the earliest act of bankruptcy within the three months before the filing of the petition). The debtor's bankruptcy is deemed to commence at that date, and the debtor's property also vests in the trustee as of that date. This enables a trustee to overturn transactions to the detriment of the estate that were entered into by the debtor from that date onward. ${ }^{97}$ The Law Reform Commission recommended that the doctrine of relation back be retained in an "adapted" version, and recommended a period of three months preceding the filing of the bankruptcy petition. ${ }^{98}$ In contrast, the SubCommittee on Insolvency recommended the abolition of the doctrine. ${ }^{99}$ Section 30 of the Bankruptcy (Amendment) Ordinance, which substitutes new s. 42 of the Bankruptcy Ordinance, rightly adopts the views of the SubCommittee. It is based on s. 284 of the UK Insolvency Act 1986, pursuant to which certain post-petition dispositions of the bankrupt may be recovered by the trustee.

\section{Proof of debt}

Many amendments have been made to s. 34 of the Bankruptcy Ordinance that improve the guidelines for provable debts. ${ }^{100}$ Section $34(1)$ has been amended to allow proofs of debts for unliquidated tort claims to be admitted in bankruptcy. This important change in Hong Kong bankruptcy law abolishes the archaic distinction between unliquidated contract claims (which have been allowed) and unliquidated tort claims (which have not). These changes reflect the views of the Cork Report:

"It is a basic principle of the law of insolvency that every debt or liability capable of being expressed in money terms should be eligible for proof in the insolvency proceedings, so that the insolvency administration should deal comprehensively with, and in one way or another discharge, all such debts and liabilities." 101

\footnotetext{
96. See US Bankruptcy Code, s. 522.

97. See the Report on Bankruptcy, op. cit., n. 5, paras 14.2-14.4, at pp. 133-134.

98. Ibid., para. 14.10 , at p. 136 .

99. Consultative Document on Bankruptcy,
}

op. cit., n. 4, para. 15.16, at p. 129.

100. See Bankruptcy (Amendment) Ordinance, s. 25.

101. Cork Report, op. cit., n.9, para. 1289 (quoted in the Report on Bankruptcy, op. cit., n.5, para. 15.5 , at p. 140 ). 
Of course, the law must provide a mechanism for valuing unliquidated claims. Amended s. 34(4) provides that the trustee should either (a) make an estimate of the value of the debt or liability or (b) refer such debt or liability to the court for valuation. Section 34(7), in turn, provides that the court "may direct the value to be assessed before the court itself without the intervention of a jury". It is unfortunate that the recent amendments do not set forth a more comprehensive valuation procedure. ${ }^{102}$

The new legislation also includes provisions addressing issues involving claims in foreign currency and currency conversion matters. New s. 34(3B) requires that the value of foreign currency debts should be determined by converting the amount of such debts into a Hong Kong dollar equivalent as of the date of the making of the bankruptcy order. This will change the existing practice, which has been to convert foreign currency debts as of the date of the receiving order. ${ }^{103}$

New s. 34(3C) permits the trustee to pay dividends in respect of foreign currency claims either in Hong Kong dollars or in the foreign currency equivalent of Hong Kong dollars. When payment is made in the foreign currency equivalent, the amount of the dividend is to be determined by using the conversion rate as of the date of the payment of the dividend.

A third change to the law regarding foreign currency appears in new s. $61(\mathrm{k}),{ }^{104}$ which permits the trustee (with the permission of the creditors' committee and after taking expert advice) to delay conversion of foreign currency into Hong Kong dollars. This change will provide the trustee with flexibility when dealing with assets in foreign currencies. ${ }^{105}$

New s. $34(3 \mathrm{~A})$ provides that no government fine or monetary penalty will be admissible to proof. Such fines and penalties will thereby not be released by the bankrupt's discharge. ${ }^{106}$ This was also the recommendation of the Cork Report, ${ }^{107}$ which, in turn, was incorporated into UK insolvency law. ${ }^{108}$ This amendment changes the current treatment of such debts in Hong Kong, because although the Bankruptcy Ordinance has not provided that fines and penalties are provable, the practice has been that they are. ${ }^{109}$ The incorporation of this new provision reflects the policy that the discharge should only be applicable to claims of the "honest but unfortunate debtor" 110 and not to

102. For a discussion of a proposed alternative valuation procedure, see Booth, "Recent Developments in Hong Kong Bankruptcy Law Reform", [1993] 2 IIR 120, at 146-147.

103. Report on Bankruptcy, op. cit., n. 5, para. 15.7 , at p. 140 .

104. See Bankruptcy (Amendment) Ordinance, s. 41.

105. For a more detailed discussion of the amendments relating to foreign currency claims, see Booth, "The Transnational Aspects of Hong Kong Insolvency Law', op. cit., n. 33, at pp. 74-76.

106. See s. 23 of the Bankruptcy (Amendment)
Ordinance (substituting new s. $32(5)$ in the Bankruptcy Ordinance).

107. Op. cit., n.9, para. 1330, at p. 302 (cited in Report on Bankruptcy, op. cit., n.5, para. 15.33, at p. 146).

108. See UK Insolvency Rules 1986, r. 12.3(2); UK Insolvency Act 1986, s. 281(4).

109. Report on Bankruptcy, op. cit., n. 5, para. 15.29, at p. 145

110. Local Loan Co v Hunt 292 US 234, 244 (1933) (quoted in Baird and Jackson, Cases, Problems and Materials on Bankruptcy (2nd edn, 1990), p. 810). 
penalties or fines that have been incurred by the debtor as punishment for his wrongful behaviour.

Finally, new s. 34(7A) provides that the trustee must accept or reject a proof of debt within a period, prescribed by the rules, or such longer period as the court may allow. This amendment is intended to ensure that the trustee admits claims within a reasonable time. ${ }^{11}$

\title{
XIII. Declaration and distribution of dividends
}

Amendments have been made to s. 67 of the Bankruptcy Ordinance regarding the declaration and distribution of dividends. ${ }^{112}$ Old s. 67 requires, as a rule, that the first dividend be declared and distributed within four months of the first meeting of creditors with subsequent dividends being declared and distributed at intervals not exceeding six months. The Official Receiver has found these guidelines to be impractical and recommended the adoption of the approach of s. 324(1) of the UK Insolvency Act 1986, which abolishes the imposition of a time frame. ${ }^{113}$ These changes have been incorporated into new s. $67(1)$, which provides as follows:

\begin{abstract}
"Whenever the trustee has sufficient funds in hand for the purpose he shall, subject to the retention of such sums as may be necessary for the expenses of the bankruptcy, declare and distribute dividends among the creditors in respect of the bankruptcy debts which they have respectively proved."
\end{abstract}

\section{Discharge}

The amendments regarding the discharge of bankrupts are among the most important changes included in the Bankruptcy (Amendment) Ordinance. ${ }^{114}$ Although it is true that old s. 30 set out procedures providing for the discharge of bankrupts, in practice, bankruptcy has been a "life sentence" for most bankrupts in Hong Kong. ${ }^{115}$ For example, in the 10-year period from 1983 to 1992 , only 25 of roughly 2,400 bankrupts were discharged. ${ }^{116}$ The old requirements for discharge have clearly become insurmountable for the vast majority of bankrupts.

The new discharge provisions, which incorporate aspects from both UK and Australian law, reflect the modern trend to enable most bankrupts to emerge from bankruptcy with a "fresh start" after a reasonable period of time. In the

111. See Report on Bankruptcy, op. cit., n. 5, paras 15.52-15.55, at p. 151 .

112. See Bankruptcy (Amendment) Ordinance, s. 43.

113. See Report on Bankruptcy, op. cit., n. 5, paras 16.4-16.5, at p. 154 .
114. See Bankruptcy (Amendment) Ordinance, s. 20 (substituting new ss $30-30 \mathrm{C}$ in the Bankruptcy Ordinance).

115. Report on Bankruptcy, op. cit., n.5, para. 17.1, at p. 156.

116. Ibid., para. 17.8, at p. 161 . 
case of a person not previously adjudged bankrupt, new s. 30A(2) (a) provides for the automatic discharge of the bankrupt at the end of four years from the date of the making of a bankruptcy order. In the case of a person who has been previously adjudged bankrupt, s. 30A(2)(b) delays the discharge for an additional year. However, s. $30 \mathrm{~A}(3)$ provides that the date of discharge may be extended for specified periods in cases in which the trustee or a creditor raises a valid objection pursuant to new s. 30A(4). These objections incorporate parts of the Australian Bankruptcy Act 1966 and the Australian Bankruptcy Amendment Act 1991. Among the objections which may be raised are the following: that a first-time bankrupt is likely within five years of the date of the bankruptcy order to be able to make a significant contribution to his estate; that the bankrupt's discharge would prejudice the administration of his estate; that the bankrupt has failed to co-operate in the administration of his estate; that the bankrupt's conduct has been unsatisfactory; that the bankrupt has departed from Hong Kong and failed to comply with a request by the Official Receiver or trustee to return to Hong Kong; that the bankrupt has continued to trade after knowing that he was insolvent; that the bankrupt has committed a bankruptcy offence; and that the bankrupt has failed to prepare an annual report for the trustee.

New s. $30 \mathrm{~A}(9)$ provides that a bankrupt who receives a discharge may be required to continue contributing to his estate for up to eight years from the date of the bankruptcy order. New s. 30B allows bankrupts to apply to the court for an early discharge. In essence, the harshness of the former discharge regime has been replaced with a new regime that offers attractive inducements for bankrupts to co-operate (e.g. the automatic discharge or an early discharge) and serious repercussions for bankrupts who fail to co-operate (e.g. the filing of objections by the trustee or creditors, which are likely to result in a delay in the making of the discharge).

Transitional provisions have also been included in the recent amendments to remedy the situation of the thousands of bankrupts in Hong Kong who have been adjudicated bankrupt under the old bankruptcy law. New s. 30C of the Bankruptcy Ordinance provides, as a rule, that individuals who have been bankrupt for four years or more (or five years or more in the case of individuals who have previously been made bankrupt) shall be deemed to be discharged from the bankruptcy one year after the day that the new discharge provisions come into operation, except in those cases in which the trustee or a creditor raises a valid objection.

\section{$\mathrm{XV}$. Statutory undertakings}

Although the Bankruptcy Ordinance has been silent as to whether utility companies are required to supply services to bankrupts in Hong Kong, in practice utility companies co-operate with bankruptcy trustees and do not demand payment of pre-petition charges as a precondition to supplying the 
trustees with services. ${ }^{117}$ New s. 30E of the Bankruptcy Ordinance formalises this practice for the public suppliers of gas, electricity, water and telecommunications when dealing with the Official Receiver, a trustee in a bankruptcy, or a nominee in a voluntary arrangement. ${ }^{18}$ This section also enables the suppliers to require the trustee or nominee to guarantee personally the payment in respect of new charges incurred during the bankruptcy or the voluntary arrangement.

\section{Interest on debts}

Matters involving interest on debt are dealt with by s. 71 of the Bankruptcy Ordinance. This section is also applicable in company liquidations pursuant to s. 264 of the Companies Ordinance. The Law Reform Commission had intended to amend old s. 71 later in the reform process, and only decided to incorporate recommendations into its Report on Bankruptcy after receiving submissions from practitioners seeking an urgent amendment to this section. ${ }^{19}$ The problem in old s. 71 has been the provision in subs. (1) which limits interest on debts bearing interest to eight per cent per annum up to the date of the receiving order. In compulsory liquidations, the limitation applies up to the date of the filing of the liquidation petition. ${ }^{120}$ This restriction causes especially serious problems in company liquidations. As the Law Reform Commission noted, when a bank is wound up, this provision requires the liquidator to recalculate the interest on any account with an interest rate greater than eight per cent. In some cases, this involves reviewing thousands of accounts over a number of years. ${ }^{121}$ This provision has long outlived its usefulness.

Section 44 of the Bankruptcy (Amendment) Ordinance abolishes the eight per cent limitation, and substitutes new s. 71(1) which provides that interest is provable up to the time of the commencement of the bankruptcy. New s. 71(2) and (3) includes guidelines regarding the payment of interest out of the surplus remaining after the payment of provable debts. It sets the rate of interest at the higher of judgment rate or the contractual rate. Finally, new subs. (4) applies to debts for which interest is not reserved or agreed for, and which are overdue at the commencement of the bankruptcy. In such cases, interest may be claimed at the judgment rate from the time the debt was payable up to the date of the commencement of the bankruptcy.

Tied to the abolition of the eight per cent limitation is the enactment of new s. $71 \mathrm{~A}$ of the Bankruptcy Ordinance, which is modelled on the extortionate credit transactions provision of s. 343 of the UK Insolvency Act 1986. This provision provides that on the application of the trustee, the court is empowered to make an order with regard to extortionate credit transactions entered into within three years of the commencement of the bankruptcy.

117. Ibid., paras 18.2 and $18.4-18.5$, at p. 179 .

para. 19.1, at p. 182 .

118. See Bankruptcy (Amendment) Ordinance, s. 21. 120. Ibid., para. 19.4, at p. 183.

119. Report on Bankruptcy, op. cit., n. 5, 121. Ibid., para. 19.6, at p. 184.

(C) 1997 John Wiley \& Sons, Ltd.

Int. Insolv. Rev., Vol. 6: 183-209 (1997) 
Similar amendments were made to the Companies Ordinance for application in liquidations. ${ }^{122}$ These sets of amendments will greatly simplify the duties of trustees and liquidators, and improve the efficiency of insolvency proceedings.

\section{Avoidance powers}

A major weakness of the old bankruptcy law is the ineffectiveness of many of the trustee's avoidance powers, namely the fraudulent preference provisions of old s. 49 and the avoidance of settlement provisions of old s. 47 . Old s. 49 enables a trustee to avoid as a fraudulent preference, inter alia, any payment or transfer of property by a debtor to his creditor that is made (a) with the "dominant intention" to prefer the creditor, (b) within six months of the filing of the bankruptcy petition, and (c) when the debtor is unable to pay his debts as they became due. Moreover, a payment or transfer made by a debtor under the fear of legal process or as the consequence of the pressure of a creditor is not considered voluntarily made and, therefore, may not be avoided as a fraudulent preference. ${ }^{123}$ The focus on the voluntary nature of the debtor's act and therefore on the debtor's state of mind in making a transfer or payment means that the section often proves ineffective in making recoveries from creditors.

Former s. 47 has proved even less useful. ${ }^{124}$ This section enables trustees to avoid certain settlements that the debtor has made within 10 years of the debtor's bankruptcy. The provision suffers from many problems. For example, some of the exemptions are archaic. Moreover, the most frequently used defence to the trustee's attempt to avoid a settlement - that the settlement was "made in favour of a purchaser or incumbrancer in good faith and for valuable consideration" - has the potential for leading to litigation over whether there was "valuable consideration".

Section 36 of the Bankruptcy (Amendment) Ordinance abolishes these sections and replaces them with new enactments based on ss 339 to 342 and 435 of the UK Insolvency Act 1986. New s. 49 allows the trustee to challenge transactions at an undervalue and s.50, unfair preferences. New s. 51(1), in turn, sets forth the time requirements for the application of these sections: five years from the day the bankruptcy petition is filed for a transaction at an undervalue; six months for an unfair preference to a person who is not an "associate" of the debtor; and two years for an unfair preference to a person who is an "associate" of the debtor. "Associate" is defined in new s.51B. Section 51A focuses on the orders that may be made under new ss 49 and 50 .

122. See s. 43 of the Companies (Amendment) Ordinance (Ord. No. 3 of 1997, LHK), which came into operation in February 1997. This section adds new ss 264A (interest on debts) and $264 \mathrm{~B}$ (extortionate credit transactions) to the Companies Ordinance.
123. See Sharp v Jackson [1899] AC 419.

124. The same may be said of old s. 31 of the Bankruptcy Ordinance, which applies to fraudulent settlements. This section has been repealed by s.22 of the Bankruptcy (Amendment) Ordinance. 
For unfair preferences, new s.50(4) replaces the dominant "intention to prefer" test with a requirement that the debtor is influenced by a "desire" to put a creditor into an advantageous position. New s. 50(5), in turn, provides that an unfair preference by a debtor to an associate (otherwise than by reason only of being the debtor's employee) is presumed, unless the contrary is shown, to have been influenced by the debtor's desire to put the associate in an advantageous position. New s. 51(2) also requires that for an unfair preference to be avoided, the debtor must be insolvent at the time of the transfer or become insolvent as a consequence of the preference.

Pursuant to s. 49, a transaction at an undervalue may involve a gift, a transaction in consideration of marriage, or a transaction in which the transferee's consideration is "significantly less" than the value of the debtor's consideration. The requirements of s. 51(2) are more complicated as applied to transactions at an undervalue. The insolvency of a debtor is only relevant for transactions at an undervalue made between two and five years of the commencement of the bankruptcy and, in cases involving an associate (otherwise than by reason only of being the debtor's employee) within that period, the debtor is presumed to have been insolvent at the time of the transaction.

The new avoidance provisions improve upon the old law, especially in regard to transactions involving associates, but they certainly are not simpler to grasp. As has been noted about the UK equivalents, these provisions "are of Byzantine complexity". ${ }^{125}$ The new preference provisions are broader in scope than the old provisions - the new test of a "desire" to put a creditor in an advantageous position is easier to satisfy than that requiring a "dominant intention" to prefer. ${ }^{126}$ Arguably, however, the provisions do not go far enough. It would have been better for the legislation to have dropped the "desire" test and to have focused primarily on the effect of the transaction in question and on preventing "last minute grabs" by creditors. ${ }^{127}$

An important benefit of these strengthened avoidance powers is that they will probably lead to increased recoveries in many cases and thereby increase participation by creditors in the bankruptcy process.

\section{Conclusion}

Although these changes to Hong Kong bankruptcy law were enacted in an amending Ordinance, in essence they almost completely overhaul the bankruptcy process. The nineteenth century nature of the former legislation

125. Sealy and Milman, op. cit., n. 56, at p. 402: general note to 5.339 of the UK Insolvency Act 1986.

126. Unfortunately, however, it appears that a creditor's pressure for payment may continue to overcome the voluntary nature of the debtor's action and thus, in some cases, overcome the debtor's desire to prefer. See ibid., at p. 291: general note to s. 239 of the UK Insolvency Act 1986. It appears, therefore, that new s. 50 will prove most useful in attacking preferences given to associates of the debtor.

127. See, e.g., US Bankruptcy Code, s. 547. 
has given way to a modern, progressive twentieth century substitute that better reflects, and will better regulate, existing commercial and social practices. Archaic notions such as acts of bankruptcy and reputed ownership have been abolished. A regime premised on wrongdoing by the debtor, on stigmatising the debtor, and on making it difficult, if not impossible, for many debtors to be discharged, has been transformed into a regime that acknowledges that many bankrupts are not morally blameworthy and that a discharge should be more of a right than a privilege.

Other trends are evident in the numerous changes to the law. Many of the attempts to modernise the law have also led to streamlining and simplifying the bankruptcy process. For example, the two-step procedure-based on a receiving order and an adjudication order - has been replaced with a onestep bankruptcy order. (Changes such as these also bring the bankruptcy ordinance into sync with existing procedures for corporate insolvency.) The doctrine of relation back has been abolished, unliquidated tort claims will be admitted, the interest on debt rules have been improved, and many unnecessary hurdles for the Official Receiver, trustees, and creditors have been removed. There are exceptions, of course. Although the new avoidance powers improve upon the old provisions, their statutory language certainly does not appear any simpler to parse.

With the streamlining will come savings in costs, from which the unsecured creditors will benefit. Unsecured creditors will also benefit from the new avoidance powers, the voluntary arrangement procedure, the new jurisdictional criteria, many of the changes regarding proofs of debt, and the decrease in the statutory deposit. Other changes will prove attractive to debtors, such as the automatic discharge, the liberalised exemptions, the ability to remain in the family home for between six and 12 months, the ability to retain legal representation at a public examination, and the doubling of the minimum debt. Overall, the new enactments do a much better job of balancing the interests of debtors and unsecured creditors. It is unfortunate, however, that secured creditors will remain able, for the most part, to continue to act outside the bankruptcy process.

Although many of the reforms strike a reasonable balance between the Official Receiver and the unsecured creditors, a few significant changes unfortunately diminish the role to be placed by unsecured creditors in the bankruptcy process. Most notable is the amendment giving the Official Receiver the ability to cancel the first meeting of creditors and to decide whether to serve as the trustee. Regrettably, the Report on Bankruptcy does not give high enough priority to increasing creditor participation (although, to be fair to the Law Reform Commission, some of its reforms - such as improving the avoidance powers - may well have that effect). In fact, many of the proposals to streamline the bankruptcy process - such as lowering the quorum for meetings of creditors to one creditor present or represented - seem to take poor creditor participation as given. 
It is significant that these changes to the law will probably come into operation shortly after the transfer of Hong Kong's sovereignty to China. Some amendments, such as retaining a petitioning ground that is based on the absconding of a debtor and increasing the time period for some of the jurisdictional criteria, are fitting solutions to problems related to the hand-over. Other changes, however, such as increasing the role played by the Official Receiver, are misguided.

The legislation could also be improved in a few other areas. For example, the jurisdictional criteria should include a criterion based on the presence of assets in Hong Kong; the trustee's avoidance powers should be further improved; the stay should be extended to secured creditors; there should be monetary limits for the bankrupt's exempt property and the exemption provisions should include more detailed guidelines; a more comprehensive procedure for valuing unliquidated claims should be included; and the provision enabling the court to order the Commissioner of Inland Revenue to produce tax documents should be applicable to the public examination of a bankrupt.

These shortcomings, however, must be kept in the proper perspective. Overall, the enactment of the Bankruptcy (Amendment) Ordinance is a major development that will greatly improve Hong Kong bankruptcy law. Many of the changes are long overdue. Indeed, it is ironic that the change in Hong Kong's sovereignty appears to have been the impetus for the Government to focus on the need to reform Hong Kong bankruptcy law and to enact a more modern statute. 